\title{
Causes of enucleation as seen in Jerusalem
}

\author{
K. L. BATTEN \\ The St. John Ophthalmic Hospital, Jerusalem
}

Following the report on causes of enucleation in Uganda (Davanger, 1970), it was felt desirable to make a similar study of cases seen at our hospital in Jerusalem. This comparison is likely to prove interesting because therapeutic developments may be expected to alter the pattern of cause and effect in the coming years.

\section{Material}

The data were collected from the hospital records for the years 1965 to 1969 . During the first half of the period the hospital with its eighty beds was situated in Jordan and drew patients from all over the Middle East and beyond, but since June, 1967, it has been in the territory annexed by Israel. Some patients continued to come from Arab countries by Red Cross permit or under family reunion schemes, but most of them are now drawn from the million or so Arabs resident within Israeli-administered territory.

During the 5-year period, 409 eyes were removed by enucleation (the majority), evisceration, and exenteration of the orbit (2 cases only). Data were available for more detailed analysis for only 235 of the total. As in Uganda, almost all were treated as inpatients and the indications for enucleation were similar to those accepted in Europe.

\section{Findings}

The number of enucleations was calculated as a percentage of all outpatients, and also of all inpatients and of all operations on inpatients at the St. John Ophthalmic Hospital, These are compared in Table I, as in Davanger's article. The St. John's figures fall between those of Uganda and Berlin and the later figures from Basel.

Table I Cases of enucleation as percentage of patients and operations compared with figures from Uganda, Basel, and Berlin

\begin{tabular}{|c|c|c|c|c|c|c|}
\hline \multirow{2}{*}{$\frac{\text { Hospital }}{\text { Cases }}$} & \multicolumn{2}{|c|}{ St. John Hospital, $1965^{-69}$} & \multirow{2}{*}{$\frac{\text { Uganda }}{1963-67}$} & \multicolumn{2}{|l|}{ Basel } & \multirow{2}{*}{$\frac{\text { Berlin }}{\mathbf{1 9 2 5 - 3 5}}$} \\
\hline & $\begin{array}{l}\text { Total } \\
\text { new cases }\end{array}$ & $\begin{array}{l}\text { Per cent. eyes } \\
\text { enucleated }\end{array}$ & & I935-39 & $195^{0}-54$ & \\
\hline Outpatients & I 42,490 & $0 \cdot 29$ & $0 \cdot 2$ & $0 \cdot 5$ & $0 \cdot 2$ & $0 \cdot 5$ \\
\hline Inpatients & I 2, I 26 & $3 \cdot 4$ & $5 \cdot 4$ & $4 \cdot 7$ & $2 \cdot 0$ & - \\
\hline Eye operations on inpatients & 9,678 & $4 \cdot 2$ & $8 \cdot 4$ & $7 \cdot 2$ & $3 \cdot 4$ & $5 \cdot 6$ \\
\hline
\end{tabular}

CAUSES OF ENUCLEATION (Table II, opposite)

An effort was made to discover the primary cause, i.e. the condition leading to removal of the eye, the immediate cause being of less interest. The frequent lack of a reliable history and the frequent appearance of a generally "disorganized eye" account for the large 
Table II Causes of enucleation by diagnosis and sex in order of frequency

\begin{tabular}{|c|c|c|c|c|c|c|c|c|}
\hline \multirow{3}{*}{\multicolumn{2}{|c|}{ Diagnosis }} & \multirow{2}{*}{\multicolumn{2}{|c|}{ Total cases }} & \multicolumn{4}{|l|}{ Sex } & \multirow{4}{*}{$\begin{array}{l}\text { Male : female } \\
\text { ratio } \\
\mathrm{I} \cdot 6: \mathrm{I}\end{array}$} \\
\hline & & & & \multicolumn{2}{|c|}{ Male } & \multicolumn{2}{|c|}{ Female } & \\
\hline & & \multirow{2}{*}{$\begin{array}{l}\text { No. } \\
60\end{array}$} & \multirow{2}{*}{$\frac{\text { Per cent. }}{25}$} & \multirow{2}{*}{$\frac{\bar{N} \text { No. }}{37}$} & \multirow{2}{*}{$\frac{\text { Per cent. }}{27}$} & \multirow{2}{*}{$\frac{\text { No. }}{23}$} & \multirow{2}{*}{$\frac{\text { Per cent. }}{24}$} & \\
\hline (I) & Painful blind eye & & & & & & & \\
\hline (2) & Corneal disease & 59 & 25 & $3^{I}$ & 23 & 28 & 29 & $I \cdot I: I$ \\
\hline （3） & Trauma & 43 & 18 & $3 \mathrm{I}$ & 23 & 12 & 12 & $2 \cdot 6: 1$ \\
\hline (4) & Phthisis bulbi & 33 & 14 & 13 & 9 & 20 & $2 \mathrm{I}$ & $0.65: 1$ \\
\hline （5） & Panophthalmitis & I5 & 6 & 12 & 9 & 3 & 3 & $4 \cdot 0: 1$ \\
\hline (6) & Glaucoma & 13 & 5 & 8 & 6 & 5 & 5 & I $6: 1$ \\
\hline (7) & Malignant tumour & 12 & 5 & 6 & 4 & 6 & 6 & $1 \cdot 0: I^{*}$ \\
\hline \multicolumn{2}{|c|}{ Total } & \multicolumn{2}{|l|}{235} & \multicolumn{2}{|l|}{${ }_{138}$} & \multicolumn{2}{|l|}{97} & \\
\hline
\end{tabular}

*o to 9 year Age group $5: \mathbf{r}$

number in the "painful blind eye" group. The Middle East appears to be a peaceable place compared with Uganda, as known trauma appears in only 18 per cent. of cases compared with Uganda's 30 per cent.

(1) Painful blind eye

Had the primary cause been known, it is reasonable to suppose that these cases would have been fairly evenly divided between the more specific categories.

(2) Corneal disease

Complications following corneal ulceration and infection formed the largest specific group. This is confirmed by the large number of damaged corneae which require grafting. The current average of two corneal grafts a week is only half of what is required, the limiting factor being the lack of donor material. Malnutrition was considered to be a significant factor affecting healing in only a very few cases.

Trachoma, in the late stages of entropion and trichiasis, is still common in the area, but acute trachoma is now much less frequent.

\section{(3) Trauma}

Males are more than $2 \frac{1}{2}$ times as likely to lose an eye from trauma as females. In the age group 10-29 years known trauma was the cause of enucleation in nearly one-third of cases.

\section{(4) Phthisis bulbi}

The high percentage of the ro to 29 year age group in which the cause was given as a "shrunken" "eye reflects the preference at this "marriageable age" for a patient to have a prosthesis fitted for cosmetic reasons.

\section{(5) Panophthalmitis}

It was not easy to assess the primary cause in many of these patients, as they usually presented for the first time with the fully-developed condition. In some the disease may 
have been secondary to another infection but many could perhaps have been included under corneal disease. No explanation for the 4:I male : female ratio is offered.

\section{(6) Glaucoma}

Many cases of glaucoma are not seen until the disease is far advanced. Primary cases only are included here, secondary cases being listed under their primary cause.

\section{(7) Malignant tumour}

All these cases were verified histologically. In the o to 9 year age group the male:female ratio was 5:1, but females predominated in the last three decades bringing the overall ratio to $\mathrm{I}: \mathrm{I}$. There was one malignant lymphoma and one malignant melanoma amongst the 12 cases.

\section{AGE AND SEX DistRIBUTION (Table III)}

There is a predominance of males in all age groups. Excluding the first decade the number of enucleations does not differ greatly between age groups but fewer enucleations were performed between the ages of 30 and 49 years.

Table III Age and sex distribution of causes of enucleation (male + female).

\begin{tabular}{|c|c|c|c|c|c|c|c|c|}
\hline \multirow{3}{*}{ Diagnosis } & \multicolumn{8}{|c|}{ Age group (yrs) } \\
\hline & $0-9$ & $10-19$ & $20-29$ & $30-39$ & $40-49$ & $50-59$ & $60-69$ & $70+$ \\
\hline & No. $\begin{array}{l}\text { Per } \\
\text { cent. }\end{array}$ & $\begin{array}{l}\text { Per } \\
\text { No. } \\
\text { cent. }\end{array}$ & $\begin{array}{ll}\text { Per } \\
\text { No. }\end{array}$ & $\begin{array}{ll}\text { No. } & \text { Pert. } \\
\text { cent. }\end{array}$ & No. $\begin{array}{l}\text { Per } \\
\text { cent. }\end{array}$ & $\begin{array}{ll} & \text { Per } \\
\text { No. } & \text { cent. }\end{array}$ & $\begin{array}{ll} & \text { Per } \\
\text { No. } & \text { cent. }\end{array}$ & $\begin{array}{l}\text { Per } \\
\text { No. cont. }\end{array}$ \\
\hline Painful blind eye & $(1+0)^{5}$ & $(2+1)^{9}$ & $(5+16$ & $\begin{array}{l}8 \\
(4+4)\end{array}$ & $\begin{array}{l}8 \\
(6+2)\end{array}$ & $\begin{array}{l}13+38 \\
(9+4)\end{array}$ & $\left(\begin{array}{l}9 \\
(5+4)\end{array}\right.$ & $\begin{array}{l}13+42 \\
(7+6)\end{array}$ \\
\hline Corneal disease & $\frac{6}{(4+2)}$ & $\left(\begin{array}{l}9 \\
(2+7)\end{array}\right.$ & $\begin{array}{l}8 \\
(7+1)\end{array}$ & $\left(\begin{array}{l}7 \\
(4+3)\end{array}\right.$ & $\begin{array}{l}6 \\
(2+4)\end{array}$ & $\begin{array}{l}8 \\
(5+3)\end{array}$ & $\begin{array}{l}10 \\
(4+6)\end{array}$ & $(3+2)$ \\
\hline Trauma & $\left(\begin{array}{l}4 \\
(3+1)\end{array}\right.$ & $\begin{array}{l}10 \\
(8+2)\end{array}$ & $\left(\begin{array}{c}9 \\
(6+3)\end{array}\right.$ & $\left(\begin{array}{l}4 \\
4\end{array}+0\right)$ & $\begin{array}{l}6 \\
(4+2)\end{array}$ & $\begin{array}{c}2 \\
(0+2)\end{array}$ & $\left(\begin{array}{l}3 \\
(3+0)\end{array}\right.$ & $\begin{array}{l}5 \\
(3+2)\end{array}$ \\
\hline Phthisis bulbi & - & $\left(\frac{9}{3}+6\right)$ & $\left(\begin{array}{l}9 \\
(2+7)\end{array}\right.$ & $(2+17$ & $\left(\begin{array}{l}5 \\
(3+2)\end{array}\right.$ & $(0+2)^{6}$ & $\left(2^{3}+1\right)^{9}$ & $(1+0)^{3}$ \\
\hline Panophthalmitis & - & - & $(1+0)^{3}$ & $(0+1)^{4}$ & $(3+10$ & $(2+1)^{8}$ & $(3+0)^{9}$ & $(2+2)^{13}$ \\
\hline Glaucoma & $(1+10$ & $(1+0)^{3}$ & - & - & $(0+1)^{3}$ & $(2+2)^{12}$ & $\left(2^{3}+1\right)^{9}$ & $(2+0)^{6}$ \\
\hline Malignant tumour & $\begin{array}{l}6 \\
(5+1)\end{array}$ & $(1+0)^{3}$ & - & - & - & $(0+2)$ & $\left(0^{2}+2\right)^{6}$ & $(0+1)^{3}$ \\
\hline Total & $\stackrel{19}{(14+5)}$ & $33(17+16)$ & 32 & ${ }^{24}(14+10)$ & ${ }^{29}(18+11)$ & $(18+16)$ & $\stackrel{33}{(19+14)}$ & ${ }^{31}(18+13)$ \\
\hline Male : female ratio & $2 \cdot 8: 1$ & I: I & $1 \cdot 3: 1$ & $1 \cdot 4: 1$ & $1 \cdot 6: 1$ & $I \cdot I: I$ & $1 \cdot 3: 1$ & $1.4: 1$ \\
\hline
\end{tabular}

\section{Summary}

The primary causes of enucleations at the St. John Ophthalmic Hospital, Jerusalem, are reviewed and compared with those in a similar report from Uganda. Corneal disease is the most important cause ( 25 per cent.) and next in importance is trauma ( 18 per cent.).

\section{References}

ammann, P. B. (1962) Klin. Mbl. Augenheilk., 140, 238

DAVANGER, M. (1970) Brit. F. Ophthal., 54, 252

KUMING, B. S., and POLITZER, W. M. (I967) Ibid., 51, 649

TEMPLETon, A. C. (1967) Cancer (Philad.), 20, 1689 